Olaoye, Ayoola Azeez, Bsc (Ed), (Acct), Msc (Acct) \& ACA

Doctoral Student, Department of Accounting, Ekiti State University, Ado-Ekiti, Nigeria

olaoyeazeez@gmail.com

\title{
A REVIEW OF AFTER INTERNATIONAL FINANCIAL REPORTING STANDARDS ADOPTION IMPACT ON FINANCIAL STATEMENTS OF COMPANIES: EVIDENCE FROM NIGERIA
}

Received: January 7, 2021

Accepted: June 30, 2019

https://doi.org/10.46458/27121097.2021.27.149

Review

\begin{abstract}
Globalization of business operations has compelled many countries across the globe to adopt the International Financial Reporting Standards (IFRS). However, continuous review of the impact of IFRS adoption is imperative to business stakeholders and accounting standards setters. This study therefore, reviewed the impact of after adopting IFRS on the global relevance of the locally produced financial statements of companies in Nigeria. The study employed a survey research design and made use of primary source of data to obtain responses through the questionnaire. A sample of ninety-six (96) respondents comprising forty-eight (48) accountants and forty-eight (48) Accounting Lecturers was purposively selected based on their availability. Multiple regression models which include regression model summary, analysis of variances (ANOVA) and Pearson correlation were used to analysis the data at 5\% level of significant using the Statistical Packages for Social Sciences version 20. Findings from the study revealed that the F-statistics of the ANOVA is positive (4910.868) and statistically significant $(0.00<0.05$.). The study therefore concluded that the IFRS, after its adoption exert positive impact by adding value to the volume of accounting information generated; improving the quality of accounting reports and enhancing global relevance of financial statements in Nigeria. The study recommended that those companies that are yet to migrate to IFRS should do so for them to enjoy the benefits of its adoption.
\end{abstract}


Keywords: After IFRS adoption impact, companies'financial Statements

JEL: M20, M41, M48

\section{INTRODUCTION}

The global convergence of accounting standards has attracted the attention of academic and professional in accounting. The global widespread of the latest standard demonstrated a new era in the accounting architect and financial reporting practices. For the past many decades, businesses have become global activities and cross border listing is now a common place where the accounting firms used to follow their growing corporate clients into other countries to gain their services (Okundi, 2013). Thus, for business organizations in Nigeria to attract finances from foreign investors, it is necessary to adopt global financial reporting benchmarks that are understood and acceptable. Meanwhile, the stakeholders of business organizations and accounting standards setting bodies require regular updating and feedback on the IFRS in order to monitor its after adoption socio-economic impacts on the world economy. A review of relevant literature confirmed that IFRS have been adopted by many countries and international communities as a basis for financial reporting. Russia adopted IFRS in 2004 (Okundi, 2013). The European Union adopted IFRS in 2005 in 2007 (Okundi, 2013). Australia and New Zealand adopted national standards described as IFRS equivalents and Switzerland permitted the use of IFRS or United States Generally Accepted Accounting Principles of financial reporting (Alistair, 2010). Ecuador adopted IFRS in 2008. Chile adopted IFRS in 2009. Brazil adopted IFRS in 2010 (Okundi, 2013). Hong Kong adopted national standards that are identical to IFRS standards and China listed 150 companies on the Hong Kong Exchange (Cai \& Wong, 2010). Canada, India, Japan and Korea also adopted IFRS in 2011 (Cai \& Wong, 2010). In Africa, many countries such as Algeria, Benin, Botswana, Gambia, Ghana, Kenya, Malawi, Namibia, N-Sudan, Rwanda, Sierra Leone, South Africa, Nigeria, Tanzania, Uganda, Zimbabwe and many others also have adopted IFRS (Okundi, 2013).

Surprising, many business organizations' accountants have not taken the adoption for serious, while thousands of accounting lecturers in the country are yet to alter their teaching methods to account for the IFRS adoption and prepare their students (the future accountants) for the new challenges. Some reviewed studies such as Abata (2015); Ironkwe and Oglekwu (2016); Elosiuba and Okoye (201) among others have confirmed that some countries in Africa did not see the adoption of IFRSs as a thing that could produce a more credible financial report. Only 
few numbers of African countries have transmitted to the latest global accounting standard (Elosiuba \& Okoye, 2018). A review of some related studies such as Nigerian Accounting Standard Board (NASB) (2010); Cai and Wong (2010); Osunwole (2013); Muhammad (2012), Abata (2015), Ironkwe and Oglekwu (2016) among others also have concentrated their investigations widely on the possible positive impact of IFRS if adopted, on the financial performance and reports of firms, but after IFRS adoption studies that will give the feedback to accounting standards setters and business stakeholders, and confirm whether the adoption of the global standard has made positive impact on the global relevance of firms' financial statements are very few in literature especially in Nigeria. However, the outcome from this study on completion will discover after adoption impact of IFRS; assist the companies' stakeholders to appreciate the need for the full adoption and compliance with IFRS benchmarks and help the accounting standards setters such as International Accounting Standards Board (IASB) to monitor the progress or otherwise of IFRS adoption in Nigeria.

\section{Research Questions:}

Based on the above background, the study raised some empirical research questions that:

a. Does International Financial Reporting Standards adoption improve the quality of financial statements of firms in Nigeria?

b. Does International Financial Reporting Standards adoption enhance the cross boarder acceptability of financial statements of Nigerian firms?

c. Does International Financial Reporting Standards adoption add value to the volume of accounting information generated from the financial statements of Nigerian firms?

\section{Objectives of the Study:}

The broad objective of this study is to examine the effect of after adopting International Financial Reporting Standards (IFRS) on the global relevance of financial statements of some selected companies in Nigeria. The specific objectives of the study are to:

a. evaluate whether International Financial Reporting Standards adoption improves the quality of financial statements of firms in Nigeria. 
b. examine whether International Financial Reporting Standards adoption enhances the cross boarder acceptability of financial statements of Nigerian firm.

c. determine whether International Financial Reporting Standards adoption adds value to the volume of accounting information generated from the financial statements of Nigerian firms.

\section{Hypotheses of the Study:}

The study hypothesized that:

a. $\mathrm{H}_{0}$ : International Financial Reporting Standards adoption does not improve the quality of financial statements of firms in Nigeria.

b. $\mathrm{H}_{0}$ : International Financial Reporting Standards adoption does not enhance the cross boarder acceptability of financial statements of Nigerian firms.

c. $\mathrm{H}_{0}$ : International Financial Reporting Standards adoption does not add value to the volume of accounting information generated from the financial statements of Nigerian firms.

\section{LITERATURE REVIEW}

\subsection{Relevance of IFRS Adoption on Firms' Financial Statements in Nigeria}

The need to attract more capital funds from foreign investors, creditors and financial institutions for the business expansion and the establishment of new ones require adoption of latest global standards called IFRS (Winney, Marshall, Bender and Swiger, 2011). The adoption of the standard became necessary across the countries given the enormous benefits it provides to the multinational companies. IFRS is a single set of high quality and globally accepted accounting standards that enhance globally comparability, relevance and acceptability of financial reports. In order to satisfying the global requirement, the International Accounting Standard Committee (IASC) established in 1973 was reformed and renamed as International Accounting Standards Board (IASB) in London in 2001 (Osunwole, 2013). The Board was saddled with responsibilities among others to introduce a new set of standards titled "International Financial Reporting Standards (IFRS) (Osunwole, 2013). The Board consists of 14 members from around the world (Osunwole, 2013). IASB (2007) explained that the term IFRS consists of IFRS 
issued by IASB; International Accounting Standard (IAS) issued by International Accounting Standard Committee (IASC); interpretations issued by the standard interpretations Committee (SIC) and the International Financial Reporting Interpretation Committee. IASB (2007) claimed that both IFRS and IAS are equally enforceable because there is no difference between the two standards. Having a single set of financial reporting standards will increase market liquidity, decrease transaction costs for investors, lower cost of capital and facilitate international capital formation and flows (Ironkwe et al., 2016). Before the introduction of International Financial Reporting Standards (IFRS), different countries developed their own national accounting standards or adopted that of other countries. When financial statements are prepared under different countries' accounting standards, they are globally often not comparable (Anao, 2012). If one company gives financial reports under Ghanaian accounting standards (GNAS) and another under United States' accounting standards (U. S. GAAP), an investor will not be able to put the two together without making a number of adjustments to accounting entries of the two companies (Anao, 2012). Without adjustments, the comparison becomes difficult and meaningless (Anao, 2012).

For business organizations in Nigeria to attract finances from multilateral organizations and foreign investors, it makes sense to adopt global financial reporting that are globally understood and acceptable. The move to adopt IFRS in Nigeria began on July 28, 2010 when the Nigerian FederalExecutive Council (FEC) approved January 2012 as theffective date for the convergence to IFRS (Ezeani, 2012). During the process of the adoption, the Act that prorogated the Nigeria Accounting Standards Board (NASB) was cancelled and replaced with the act enacting Financial Reporting Council of Nigeria (FRCN) to ensure seemly IFRS adoption. Nigeria eventually adopted IFRS in 2011. The former Nigerian President, Good-luck Ebele Jonathan repealed the Nigerian Accounting Standard Board Act No 22, 2003 and enacted the Financial Reporting Council of Nigeria (FRCN) Act 2011 (Aganga, 2011). The FRCN is a unified independent regulatory body for accounting, auditing, actuarial, valuation and corporate governance (Aganga, 2011). Goodlock Jonathan therefore charged the Chief ExecutiveOfficer of the FRCN, Mr Obazee, to liaise with the Nigeria accounting professional bodies and the regulatory bodies of tertiary institutions with a view to reviewing the accounting curricula that will reflect the studies of IFRS in the syllabus of higher institutions and accounting professional bodies (Aganga, 2011). In September 2010 the adoption was launched and structured in such a way that all the stakeholders will be using the IFRS by January, 2014 (Aganga, 2011). The public interest entities quoted on the Nigeria Stock Exchange with a minimum of $\mathrm{N} 500 \mathrm{~m}$ in shareholders' funds were required to commence implementation by January, 2012 (Aganga, 2011). Other Public Interest entities quoted on the Nigerian Stock Exchange but with Share holders' funds below N500m were required 
to commence implementation by January 2013 (Aganga, 2011). Then the Small and Medium Scale Enterprises (SMEs) were required to commence implementation by January 2014 (Aganga, 2011). Subsequent to this announcement by the defunct NASB; several events and activities were embarked upon by both public sector entities as well as private sector organizations to ensure that the transition was seamlessly achieved (Aganga, 2011). It involved local and international conferences and workshops for the purpose of information dissemination and knowledge transfer (Aganga, 2011).

Financial Statements (FSs) is the accounting reports in respect of the economic activities of an enterprise prepared periodically and usually at the end of every financial year (Osunwole, 2013). These statements form an integral part of the company's annual accounts and reports of business entities (Osunwole, 2013). Based on the reviewed related studies, the adoption of IFRS in Nigeria has enhanced relevance of FSs in Nigeria. Several studies have confirmed that adoptions of IFRS at firms' levels have increased direct foreign investment. Muhydeen (2015) affirmed that adoption of IFRS at the firm level has enhanced accounting quality and financial performance. Cai \& Wong (2010) explained that convergence to IFRS is likely to enhance financial reporting and hence there is no need for companies to report using more than one set of accounting standards. Ajibade (2011) confirmed that the adoption of IFRS is a means of lowering the cost of capital and providing greater market liquidity. The adoption and implementation of IFRSs in Nigeria has enhanced credible financial reporting in Nigeria (Akinleye, 2016). Credibility of financial statements here means that the financial report issued in Nigeria can be compared with those issued in any other country that has adopted the standard (Akinleye, 2016). With IFRSs adoption, accounting reports being prepared in Nigeria will be reliable, understandable and comparable with that of others countries (Ugbede, Mohd and Ahmad, 2014; Muhibudeen, 2015). The adoption of IFRS has forester investment decisions and ensured a more optimal allocation of resources across the economy of Nigeria (Kaaya, 2015). Adoption of IFRSs in Nigeria has enabled quoted firms to have access to international capital markets for funds raising additional funds for capital expansion (Yahaya, Yusuf \& Dania, 2015). IFRS adoption has also attracted foreign investors which resulted to Nigerian economic growth (Elosiuba et al., 2018). IFRSs adoption has made the global acceptability of locally prepared financial statements of firms in Nigeria possible (Nwakaeze, 2010). Adoption of IFRS has resulted to the reduction of accounting conversion and transactional costs abroad (Sani \& Umar, 2014). 


\subsection{Theoretical Review}

Theoretically, this study was pinned on the Value Maximization theory (VMT) introduced by Michael (2001) in Elosiuba et al. (2018) and Pure impression management model of Accountability (PIMM) propounded by Keppler (1995) in Osunwole (2013). The Value Maximization theory focused on the production of the financial statements and reports that will capture all the information expected by all stakeholders in the financial statements (Abdul-Baki, Uthman, \& Sanni, 2014). The theory explained further that all the activities of a business organization, in respect of it legal form and type should be to maximize the interests of all stakeholders and fulfill debt obligations (Elosiuba et al., 2018). However, the essence of a firm's financial statement being disclosed in compliance with IFRS is to maximize and protect the interests of all shareholders as explained in the theory of value Maximization. Additionally, the theory of pure impression management model of accountability emphasized on the observance of unified accounting standards that would serves as a linkage construct by continually reminding people of the need to act in accordance with the prevailing form and content of financial reporting (Abul-Baki, Uthman \& Sanni, 2014). The theory claimed that the financial reporting cannot be accepted by general public or investors if certain accounting standards that are globally expected are not followed. This theory recognizes that uniformity and observance of relevant accounting standards that could achieve smooth functioning and enhance good quality of the companies' annual accounts and reports (Ezeani, 2012). The theory focuses on behavioral aspect of accounting and the need to comply with the generally acceptable accounting standard and practices during the preparation of financial statements and reports of any business entity across the globe. Therefore, the Value Maximization theory and the theory of pure impression management model of accountability are relevant to this work.

\subsection{Empirical Review}

Nwakaese (2010) conducted a study on the "Regulation of financial reporting for accountability" in some selected quoted companies in Nigeria. The study found that there was a problem of accuracy of annual financial reports and accounts of some business organizations due to non- compliance with the IFRS adoption. The study concluded that without IFRS-based financial statements, barriers to cross border listing would not be eliminated and Nigerian companies would not stand a better chance of raising capital abroad because only the few companies precisely banks were listed in the foreign stock exchange. A study was conducted by Cai and Wong (2010) on the effects of IFRS adoption on global capital market integration. The study used secondary data. Findings from the study showed 
that having a single set of internationally acceptable financial reporting standards will eliminate the need for restatement of financial statements and facilitate integration of the global financial markets. Also, the result of a study carried out by Ezeani (2012) on the Adoption of IFRS to enhance financial reporting in Nigeria Universities confirmed that majority of accounting quality indicators improved after IFRS adoption. Anao (2012) examined the adoption of IFRS at firm level on FRCN Act, Nigeria Roadmap to IFRS and implication of accounting education in Nigeria.The study found that the firms that have adopted IFRS had exhibited higher accounting quality in the post-adoption period than they did in the pre-adoption period. The study concluded that few companies precisely banks were listed in the foreign stock exchange. Muhammad (2012) conducted a research on the IFRS adoption on firms' performance in Nigeria. The study used secondary data. The t-test and Logistic regression were employed to analyze data collected. Findings from the study revealed that there was an average decrease in the variability of earnings from 32624.4 to 14432.2 . This result implies that there appears a low in the variability of earnings after IFRS adoption. The study concludes that the quality of accounting has improved in the post adoption of IFRS era. Ironkwe et al. (2016) conducted a study to examine the relationship between the IFRSs and the corporate Performance of listed companies in Nigeria". The study used primary data through the questionnaire and personal interview and. Data collected were analyzed using both descriptive methods such as tables, frequencies and percentages and inferential statistics of Chi-square and ANOVA respectively. The study found a strong relationship between the IFRS adoption and the financial performance leading to reduction in the transactional costs of the firms. The study concluded that adoption of IFRS has improved the companies' productivity and the quality of accounting reporting.

\section{METHODOLOGY}

This study adapted a survey research design and made use of primary data to obtain data through the structured questionnaire from respondents to examine after adoption impact of International Financial Reporting Standards (IFRS) on the global relevance of financial statements in Nigeria. The study' population is made up of some selected firms and tertiary institutions in Nigeria. A sample of ninety-six (96) respondents comprising forty-eight (48) accountants and forty-eight (48) Accounting Lecturers was purposively selected based on their availability and considering their accounting work experience, teaching experience, job status and educational attainments. The data gathered was analyzed using the Multiple Regression Models comprising model summary, analysis of variances (ANOVA) and Pearson correlation using the Statistical Packages for Social Sciences (SPSS) version 20 for analysis. All the distributed ninety-six (96) copies 
of the questionnaires of were returned valid and analyzed. The instrument consisted of a 4-Likert scale of Strongly Agree (SA-4); Agree (A-3); Strongly Disagree (SD-2); Disagree (D-1). The validity of the questionnaires was confirmed by the expert in the field of Accountancy and the reliability of the instrument was confirmed by conducting a Cronbach's Alpha reliability test showed in table 2 .

Table 1: Reliability Statistics

\begin{tabular}{|c|c|}
\hline Cronbach's Alpha & Numbers of Items \\
\hline 0.792 & 4 \\
\hline
\end{tabular}

Source: Author's Analysis, 2020

Table 1 showed the Cronbach's Alpha coefficient test result of 79\% (0.792) which above the percentage of Cronbach's Alpha coefficient recommended by George and Mallery (2003) in Anao (2012) that the statistical reliability of 70\% percentage and above is reliable which is achieved in this study.

\section{RESULTS AND DISCUSSION OF FINDING}

This section presented and analyzed data collected to generate results for discussion in the study.

Table 2: Regression Model Summary

\begin{tabular}{|c|c|c|c|c|}
\hline Model & R & R Square & Adjusted R Square & Std. Error of the Estimate \\
\hline 1 & $0.880^{\mathrm{a}}$ & 0.774 & 0.767 & 0.44788 \\
\hline
\end{tabular}

Source: Author's Analysis, 2021. Predictor: after Adoption effect of IFRS

Table 2 showed the coefficient of relationship (R) result of 0.880 . The R-square (coefficient of determination) result reveals that $77 \%(0.774)$ of the total variation in the relevance of financial statements of firms is jointly accounted for after the adoption of the International Financial Reporting Standards (IFRS) in Nigeria while other variations in the error term accounted for the remaining $23 \%$ of variation of the global relevance of financial statements. The adjusted R-square of $76 \%(0.767)$ reveals that even if all the error terms are incorporated into the model, the adoption of IFRS will still by $76 \%(0.767)$ improve the quality of financial statements; add to the volume of accounting information generated from financial statements and enhance the cross boarder acceptability of the locally produced IFRS based financial statements in Nigeria and other countries. 
Table 3: Analysis of Variances ANOVA

\begin{tabular}{|c|c|c|c|c|c|}
\hline & $\begin{array}{c}\text { Sum of } \\
\text { Squares }\end{array}$ & Df & $\begin{array}{c}\text { Mean } \\
\text { Square }\end{array}$ & F & Sig. \\
\hline Regression & 157.969 & 1 & 157.969 & 4910.868 & 0.000 \\
Residual & 6.723 & 209 & 0.032 & & \\
Total & 164.692 & 210 & & & \\
\hline
\end{tabular}

Source: Author's Analysis, 2021. The independent variable is After Adoption effect of IFRS.

Table 3 revealed the result of the joint analysis of variances (ANOVA) of the three study's explanatory independent variables. The result indicated that f-value is positive (4910.868) and statistically significant (0.00) at 5\% level of significant. Thus the three stated study' hypotheses are jointly rejected confirming the truth of alternative hypotheses. Therefore, the study concluded that the International Financial Reporting Standards adoption has improved the quality of financial statements of firms prepared in Nigeria; enhanced the cross boarder acceptability of financial statements of Nigerian firms and added value to the volume of accounting information generated from the IFRS based financial statements of Nigerian firms.

Table 4: Pearson Correlation Analysis

\begin{tabular}{|c|c|c|c|c|}
\hline & & $\begin{array}{c}\text { Financial } \\
\text { Statements } \\
\text { Quality } \\
\text { Improvement }\end{array}$ & $\begin{array}{l}\text { Financial State- } \\
\text { ments Global Rele- } \\
\text { vance Enhancement }\end{array}$ & $\begin{array}{c}\text { Financial Statements } \\
\text { adding value } \\
\text { to the volume } \\
\text { of Accounting } \\
\text { Information }\end{array}$ \\
\hline \multirow{3}{*}{ Const. } & $\begin{array}{c}\text { Pearson } \\
\text { Correlation }\end{array}$ & 1.0000 & $0.964^{* *}$ & $0.371^{* *}$ \\
\hline & Sig. (2-tailed) & 0.000 & 0.000 & 0.000 \\
\hline & $\mathrm{N}$ & 96 & 96 & 96 \\
\hline \multirow{3}{*}{$\begin{array}{l}\text { A f t e r } \\
\text { I F R S S } \\
\text { Adoption }\end{array}$} & $\begin{array}{c}\text { Pearson Corre- } \\
\text { lation }\end{array}$ & $0.964^{* *}$ & 1.0000 & $0.345^{* *}$ \\
\hline & Sig. (2-tailed) & 0.000 & & 0.001 \\
\hline & $\mathrm{N}$ & 96 & 96 & 96 \\
\hline \multirow{2}{*}{$\begin{array}{l}\text { A } f t \text { e } r \\
\text { I F R S } \\
\text { Adoption }\end{array}$} & $\begin{array}{c}\text { Pearson } \\
\text { Correlation }\end{array}$ & $0.371^{* *}$ & $0.850^{* *}$ & 1.0000 \\
\hline & $\begin{array}{c}\text { Sig. (2-tailed) } \\
\text { N }\end{array}$ & $\begin{array}{l}0.000 \\
96\end{array}$ & $\begin{array}{l}0.001 \\
96\end{array}$ & 96 \\
\hline \multirow{2}{*}{$\begin{array}{l}\text { A f t e r } \\
\text { I F R S } \\
\text { Adoption }\end{array}$} & $\begin{array}{l}\text { Pearson } \\
\text { Correlation }\end{array}$ & $0.345^{* *}$ & $0.495^{* *}$ & $0.845^{* *}$ \\
\hline & Sig. (2-tailed) & 0.000 & 0.000 & 0.000 \\
\hline
\end{tabular}

Source: Author's Analysis, 2021 
The correlation results in table 4 showed a strong relationship of 0.964 between After IFRS adoption and improving the quality of financial statement; the correlation of 0.850 between after IFRS adoption and enhancing global relevance of financial statements and the correlation of 0.845 between after IFRS adoption and adding value to the volume of accounting information generated from financial statements. All their corresponding probabilities values $(0.00)$ are also less than $5 \%$ significant level $(0.00<0.01)$. Therefore, from all the results, the hull hypotheses are rejected. Thus, IFRS adoption in Nigeria has significant impact on the quality, global relevance and acceptability of financial statements of firms in Nigeria which also attracts many benefits.

\section{CONCLUSIONS}

Finding from this study discovered that after the adoption of International Financial Reporting Standards adoption (IFRS0 in Nigeria, the quality of financial statements of firms has improved; IFRS adoption has enhanced cross boarder acceptability of financial statements of Nigerian firms and has added value to the volume of accounting information being generated from the IFRS based locally prepared financial statements in the country. This study's results supported the results of the works of Muhammad (2012); Osunwole (2013) and Ironkwe et al. (2016) and a host of others where there-in the studies concluded that the accounting quality has improved after IFRS adoption in Nigeria. More so, the adoption of IFRS in Nigeria since 2012 has been attracting many foreign investors into the country. But some studies lamented that thousands of firms' Accountants and Accounting Lecturers of some tertiary educational institutions in Nigeria have not complied or migrated to account for the latest transformation to the globally accepted accounting and financial reporting standards. However, migration to IFRS is imperative as one of the benefits of its adoption is that it will save multi-national firms and foreign investors all over the world from incurring additional accounting conversion costs on cross border transactions. Besides, the firms that have adopted IFRS as a basis of financial reporting have stood a better change of raising capital abroad through foreign stock markets and eventually this action has contributed to economic growth of Nigeria. It is therefore recommended that other companies that are yet to migrate to IFRS should do so in order to enjoy the benefits of its adoption. 


\section{REFERENCES}

1. Abata, M. A., (2015). The impact of International Financial Reporting Standards adoption on financial reporting practice in the Nigerian banking sector. Journal of Policy and Development Studies, (9)2, 169-184.

2. Abdul-Baki Z., Uthman, A. B., \& Sanni, M. (2014). Financial ratio as performance of IFRS and Nigerian GAAP. Accounting and Management Information System, 13(1), 82-97.

3. Aganga, O. (2011). Workshop on Attracting Investment into Nigeria Held at Trascorp, HiltonHotel, Abuja July 20th 201.1

4. Ajibade, M. (2011). Financial Reporting Council (Formerly National Accounting Standard Board (NASB). In EssienAkpan (Ed). International Financial Reporting Standards (IFRS). The Role of the Chartered Secretary and Administrator. A paper presented at the $35^{\text {th }}$ Conference of Institute of Chartered Secretaries and Administrators of Nigeria (ICSAN), Lagos Sheraton Hotels and Towers, October 26th and 27th.

5. Akinleye, G.T. (2016). Effect of international financial reporting standards adoption on the performance of money deposit banks in Nigeria. European Journal of Business, Economics and Accountancy, 4(4), 87-95.

6. Anao, A. R. (2012), FRC Act and Nigeria Roadmap to IFRS: Implication of Accounting Education in Nigeria. A Paper presented at a Workshop/ Training organized by the Financial Reporting Council of Nigeria for University Lecturers in Enugu, Enugu State, Nigeria.

7. Cai, F., \& Wong, H. (2010). The Effects of IFRS adoption on global capital market integration. International Business \& Economic Research Journal, 9(10), 25-34.

8. Elosiuba, J. N. \& Okoye E. 1. (2018). Effects of International Financial Reporting Standards on corporate performance of selected banks listed on Nigeria stock exchange. Annals of Spiru Haret University Economic Series, 1, $1-28$

9. Ezeani, N. S. (2012). Adoption of international financial reporting standards (IFRS) to enhancefinancial reporting in Nigeria Universities. Arabian Journal of Business and Management Revi w (OMAN Chapter), 2(3). 
10. Ironkwe, U. I. \& Oglekwu, M. (2016). International Financial Reporting Standards and corporate performance of listed companies in Nigeria. IIARD International Journal of Banking and Finance Research, (2)3, 1-13.

11. Kaaya, I. D. (2015). The Impact of International Financial Reporting Standards on earnings management: a review of empirical evidence." Journal of Finance and Accounting, (3)3, 57-65.

12. Muhammad, T. (2012). The effect of International Financial Reporting Standards adoption on the performance of firms in Nigeria. Journal of Administrative and Economic Sciences $\backslash$ Qassim University, 5(2), 133-157.

13. Muhibudeen, L. (2015). International Financial Reporting Standard and value relevance of accounting information in quoted cement firms in Nigeria. International Journal of Sciences: Basic and Applied Research (IJSBAR), 22(1), 81-95.

14. Nigerian Accounting Standards Board(NASB) (2010). Adoption of International Financial Reporting Standards Report of the Committee on Road Map to the Adoption of IFRS.

15. Nwakaeze, E. (2010). Olamide, F. (2010). Audit quality, corporate Governance and firm characteristics in Nigeria. International Journal of Business Management December, 5 (5), 10-15.

16. Osunwole, O.O (2013). Appraisal of the role of International Financial Reporting Standards (IFR) in ensuring full disclosure of relevant information by business organizations in Nigeria. A paper presented at the $2^{\text {nd }}$ annual national conference of Falculty of Financial Studies, Osun State Polytechnic, Iree, between $23^{\text {rd }}-27^{\text {th }}$ September, 2013, 1-17.

17. Okundi, B. (2013). Tax implications of implementing IFRSs. Price Water house Coopers (n.d.). A option of IPSAS in Ghana: Prospects, Challenges and the Way Forward. Retrieved from www.acoa13.com

18. Sani, S. \& Umar, D. (2014). An assessment of compliance with IFRS framework at first -time adoption by the quoted banks in Nigeria. Journal of Finance and Accounting, 2(3), 64-73.

19. Ugbede, O., Mohd, L. \& Ahmad, K. (2014). International Financial Reporting Standards and the quality of banks financial statement information: evidence from an emerging market, Nigeria. European Journal of Business and Social Sciences, 3(8), 243-255. 
20. Winney, K. , Marshall,D ., Bender,B \& Swiger, J. (2011). Accounting Globalization: Roadblocks to IFRS Adoption in the United States, Global Review of Accounting and Finance, $167-178$.

21. Yahaya, O. A., Yusuf, M. J. \& Dania, I.S. (2015). International financial reporting standards' adoption and financial statement effects: Evidence from listed deposit money banks in Nigeria. Research Journal of Finance and Accounting, 6(12), 107-122. 
Olaoye, Ayoola Azeez, Bsc (Ed), (Acct), Msc (Acct) \& ACA

Doctoral Student, Department of Accounting, Ekiti State University, Ado-Ekiti, Nigeria

olaoyeazeez@gmail.com

\section{PREGLED UČINAKA PRIMJENE MEĐUNARODNIH STANDARDA FINANCIJSKIH IZVJEŠTAVANJA NA FINANCIJSKE IZVJEŠTAJE KOMPANIJA: PRIMJER NIGERIJE}

Primljen: 7. siječnja, 2021

Prihvaćen: 30 . lipnja, 2021

https://doi.org/10.46458/27121097.2021.27.149

Pregledni rad

\section{Sažetak}

Globalizacija poslovanja natjerala je mnoge zemlje diljem svijeta da usvoje Međunarodne standarde financijskog izvještavanja (MSFI). Međutim, kontinuirano propitivanje učinka usvajanja MSFI-ja imperativ je poslovnim sudionicima i onima koji postavljaju računovodstvene standarde. Stoga ova studija istražuje utjecaj usvajanja MSFI-ja na globalnu važnost lokalnih financijskih izvještaja $u$ Nigeriji. Studija se koristila anketnim istraživanjem kao načinom dobivanja primarnih podataka. Uzorak od devedeset i šest (96) ispitanika koji se sastoji od četrdeset osam (48) računovođa $i$ četrdeset osam (48) predavača računovodstva namjerno je odabran na temelju njihove dostupnosti. Višestruki regresijski modeli koji uključuju sažetak regresijskog modela, analizu varijanci (ANOVA) i Pearsonovu korelaciju korišteni su za analizu podataka na razini od 5\% značajnosti pomoću Statistical Packages for Social Sciences verzija 20. Nalazi iz studije otkrili su da F-statistika ANOVA je pozitivan $(4910,868)$ i statistički značajan $(0,00$ $<0$,05.). Zaključci studije ukazuju kako usvajanje MSFI ima pozitivan učinak kroz stvaranje dodane vrijednosti promatrano kroz obujam kreiranih računovodstvenih informacija; poboljšanje kvalitete računovodstvenih izvješća i povećanje globalne relevantnosti financijskih izvještaja u Nigeriji. Studija je preporučila da one tvrtke koje tek trebaju preći na MSFI to učine kako bi ostvarile koristi njihova usvajanja.

Ključne riječi: učinci primjene IFRS, financijski izvještaji poduzeća

JEL: M20, M41, M48 